\title{
Sir Harry Platt: 100 not out
}

\author{
RICHARD SMITH
}

One of the proud claims of Sir Harry Platt, Britain's first orthopaedic professor, who is 100 this month, is that he won the Ashes for England in 1932. He was summoned to Old Trafford from his popular Tuesday afternoon teaching session at Ancoats Hospital. At the cricket ground the north was playing the south in a selection match and Harold Larwood was having trouble with his knee. Sir Harry examined Larwood in the professional changing room (players were, of course, separated from gentlemen in those days), and then was summoned to give his verdict to the selectors, the chairman of whom was P F Warner. His recommendation was that if Larwood rested for the next match he would be fit to tour Australia. Warner said, "Put that in writing, and we'll send you your fee," which, Sir Harry says, was "a miserable four guineas."

So Larwood went on the famous "bodyline" tour, and England came home with the Ashes. Sir Harry still feels strongly that the idea that Larwood was bowling at the body was quite wrong and "grossly exaggerated by $T h e$ Times cricket correspondent... He was simply bowling at the leg stump." Sir Harry was particularly incensed by last year's Australian television series on the tour-he described it as "the worst television I've ever seen." Nor is he much fonder of modern cricket, in which, he says, the bowling is much more vicious than anything Larwood ever bowled: "The game's spoilt for me by the way the players hug each other-they look like copulating frogs."

Cricket is one of the few subjects that still provokes the fire for which Sir Harry was once famous. I spent a quiet and relaxing day with him in the summer, but he admitted that "irascible" had been a fair word to use about him when he was younger. "Apocryphal" was, however, how he described the story about the theatre sister getting back at him for kicking buckets in the operating theatre by filling one with plaster of Paris. But it was his determination and need for perfection that took him to the heights of the profession: after being the first in Britain to organise a fracture clinic he became the first secretary of the British Orthopaedic Association, the first orthopaedic surgeon to become president of the Royal College of Surgeons of England, and the first president of the International Federation of Surgical Colleges.
Sir Harry might easily, however, never have become a surgeon.등 The great passion of his childhood was music, and in 1903 he prepared three compositions for the Mendelssohn scholarship, $\overparen{\mathbb{\Phi}}$ which had first been won by Sir Arthur Sullivan in 1856. The scholarship went to George Dyson, who went on to become $a^{\infty}$ distinguished composer and musicologist. Sir Harry keeps close to $\vec{\circ}$ him two of the compositions he prepared for the competi- $\vec{\omega}$ tion: he is proud of his stringo quartet but his orchestral 3 . overture he describes as "feeble."

Music became a passionos for Sir Harry along with $-\rightarrow$ books ("My mother startedo meon George Eliot") because ${ }^{\triangleright}$ he was never able to plays games. At the age of 5 he developed a tuberculous? knee and ever afterwards hadôे an obvious limp. This might have been particularly $\overrightarrow{-}$ poignant for Sir Harry be-ळ cause his three brothers were. all outstanding sportsmen. But in fact he wasn't nearly as distressed as his parents, who, Sir Harry thinks, nevero quite came to terms with his尺 disability and took great $\overrightarrow{\vec{B}}$ pains to protect him during 3 his childhood and beyond.

His parents were two of the three great influences in his life, and both lived into their 90s. His father was $a_{0}^{<}$ mill owner who was "Lan-3. cashire born, inarticulate, and generous," while his mother was a "lovable,

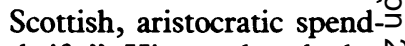
thrift." His mother had aN brother who before emigrat- $\rightarrow$ ing and becoming a rich New‥ Jersey businessman played in goal for Everton, when itN was an amateur team, and became the first man to hit a six out of the $\sigma$ New Brighton cricket ground. He it was who introduced Sir Harry to the third great influence in his life, Robert (later Sir Robert) Jones, "the greatest surgeon who ever lived."

Sir Harry's uncle insisted that he should be taken to see Robert Jones about his knee, and Sir Harry can still remember when as ao small boy his father took him to Liverpool on the train. They took a $\mathrm{\Phi}$ hackney cab to 11 Nelson Street and waited ages before "this curly headed fascinating man" came through to examine his "swollen and contracted knee." With a quick movement Robert Jones straightened the knee for the first time in a long while, and Sir Harryo cried. Thereafter, he and his father made regular visits to Nelsons Road and discovered that the way to get an early appointment wasê. "to tip old Tom, the butler." Years later Sir Harry again made? 
regular visits to Liverpool when he helped Sir Robert revise one of the standard orthopaedic textbooks.

Undoubtedly it was partly the influence of Robert Jones that decided Sir Harry - after a summer of indecision in Llandudno - to opt for medicine rather than music. He entered medical school in 1904 and found the physics and chemistry fearfully difficult because he had never studied either subject. He was in the same year as Geoffrey Jefferson, a lifelong close friend who became a neurosurgeon and who "was one of the greatest intellects to come out of the Manchester School." Sir Harry was also in the same year as four women medical students, "who were kept completely separate." He never had a chance to speak to any of them but did get to know Frances Huxley, who was two years older and, with Sir Harry, cosecretary of the university musical society. She, like several other women, including his wife, Sir Harry described "as a most beautiful woman." When I suggested that women were very important to him he demurred, but he was the first surgeon at Ancoats Hospital to appoint a woman house surgeon-and this was years before any were appointed in the Manchester Royal Infirmary.

\section{To Boston}

Sir Harry passed automatically into surgery and in retrospect thinks that he should perhaps have been a physician. By nature and as a result of his childhood he was a contemplative man and "not naturally a great craftsman because everything was done for me as a child." His greatest talents were in organisation, and over the years he was on "every committee there was" and played a big part in determining how hospitals would be staffed and organised after the NHS was founded. He still follows the organisation of the NHS and thinks that Griffiths managers are a great mistake.

After doing jobs in many of the important surgical hospitals in London he was offered the chance to go to Boston. He didn't want to go for as long as two years, but his father agreed to support him through a shorter attachment. His new chief, Dr Elliot Brackett, met him on the quayside and took him to stay at his own home. Sir Harry still remembers with excitement his first full day in Boston. He rose at $6 \mathrm{am}$, in the afternoon went to a "coming out tea" on Commonwealth Avenue, and in the evening attended a dinner party where the wife of the principal of an American college in Constantinople gave a talk on "The American woman abroad."

Sir Harry loved Boston and regards the United States as his second home. In addition to learning orthopaedics at the Massachusetts General Hospital and the Boston Children's Hospital he would go and watch Harvey Cushing operate at the Peter Bent Brigham Hospital; and he devoured what the Boston libraries had to offer. He read all the English, French, and German orthopaedic journals, and, in the music library, he read the complete score of Wagner's Ring and all the music he could find by Elgar. He describes himself as "a Wagner man" and saw both the Die Meistersinger and Tristan and Isolde in Boston-in Tristan the Italian tenor Fontana sang the famous love duet in Italian while his partner sang in German. The one thing that Sir Harry missed in Boston was tea, and eventually he found an English woman who would brew up for him at four o'clock in the children's hospital outpatients.

Soon after Sir Harry came home from America the war came, and orthopaedic surgeons were about to be in great demand. "Moynihan, Stiles from Edinburgh, and Robert Jones were the three great surgeons of the first world war," and Sir Harry told me how this came about. After visiting France Moynihan came home and told Sir Alfred Keogh, deputy commander of the Army Medical Services, that the war "would be a war of orthopaedic surgery, and you need Robert Jones in charge." Sir Alfred agreed but said that the London surgeons wouldn't like that, to which Moynihan replied, "If you don't have Robert you can't have me."

Sir Harry knew Moynihan well and is full of stories about him. He was, like some of the great surgeons Sir Harry knew, extremely egotistical, but he was also a brilliant and natural craftsman. Sir Harry went with a party of Manchester surgeons to watch Moynihan's last operation in the Leeds Royal Infirmary. He removed the biggest spleen that his audience had ever seen, with adhesions containing arteries as big as the radial artery; it was the finest operation that any of them ever witnessed.

Once Robert Jones was in charge of the wartime orthopaedic services he put Sir Harry in charge of the Manchester centre. He ultimately worked seven days a week, night and day, at trying to reconstruct the limbs and nerves of the injured men. At this time Sir Harry first began to use the no touch technique, but he still remembers one case that went wrong - a man who died of tetanus after having a bone graft. Repairing peripheral nerve injuries was Sir Harry's particular specialty, and he wrote his MD thesis on the subject, winning a gold medal for this in 1921 .

The years between the wars were years of hard work and concentrated family life. In 1932 an orthopaedic department was belatedly set up in Manchester Royal Infirmary, and Sir Harry became its first chief. A personal chair was created for him in 1939, and he was knighted in 1948 . He and his wife, a nurse who had run a hospital for officers at Chequers during the first world war, married in 1916 and had five children - four daughters and a son.

During the second world war he was an adviser to the government and again stepped up his work so that the seven working days in his week were even fuller. In an article he wrote in 1971 he described how this gave him "an exhilarating sense of being at full stretch." After the war he began to work a lot in the Royal College of Surgeons of England and was president from 1954 to 1957.

This post and his previous travels gave him great opportunities to meet people. His flat is filled with photographs not only of his family but also of orthopaedic surgeons from all over the world. Most of them are now dead, and Sir Harry is well aware that one of the disadvantages of living to such a great age is that all of your contemporaries die before you. One of the famous orthopaedic

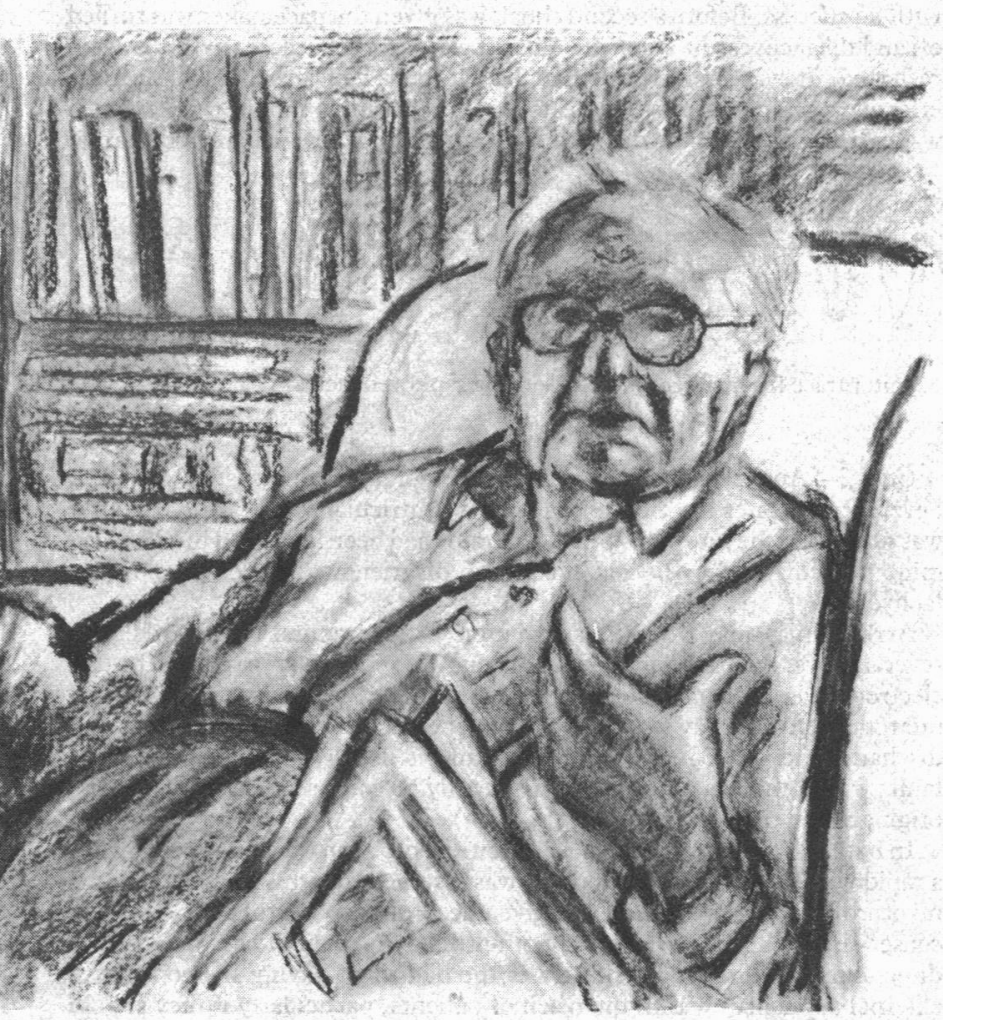


surgeons whom Sir Harry didn't have to travel far to meet was John Charnley, who worked with Sir Harry after the second world war. Charnley developed an interest in the healing of fractures in Egypt during the war but when he came back to Manchester had "never reconstructed a hip joint." Sir Harry described him as a surgical physiologist who in his plans was "like Leonardo da Vinci."

Sir Harry also met Churchill, Mussolini, Nehru, and Weizmann, who had been a lecturer in chemistry in Manchester before the first world war. Mussolini, who Sir Harry described as " "his nibs," told Sir Harry and other orthopaedic surgeons in 1936 that they were "engineers of the human body" and then returned to his woman in the Palazzo Venezia. Nehru, "a fascinating man," at an audience in New Delhi one Sunday morning asked Sir Harry whether he thought it would be a good idea if they were to produce doctors in three years in India. Sir Harry said no because that would devalue Indian medicine. Sir Harry met Churchill when he went to the Royal College of Surgeons to collect the honorary fellowship he had been awarded during the war. By then, 1956, Churchill had had three strokes, but this was not public knowledge at the time-and Sir Harry remembers being impressed by his vigour rather than by his frailty.

\section{Growing old in Manchester}

Sir Harry is now beginning to feel frail himself. It is just in the last year, he says, that he has begun to feel really old. He still reads The
Times every day, and he takes the Times Literary Supplement, Atlantic Monthly, Harpers, and the BMF (and particularly likes George Dunea and Michael O'Donnell) as well as innumerable orthopaedic and surgical journals but regrets that he is "getting behind with them."

His mind seemed crystal clear to me, but he was irritated that he forgot the occasional name (probably no more than two in five hours of conversation). I was much more impressed by how many he remembered-because you meet a lot of people in a century if you are as companionable as Sir Harry and travel as widely as he has done.

Many of those people, but particularly Robert Jones and Moynihan, came alive for me that afternoon. And they all live still in Sir Harry's dreams. He is fond of quoting from The Indian Summer of a Forsyte: "How should an old man live his days, if not dreaming of his well spent past." He feels now, however, that he has out Forsyted Old Jolyon Forsyte by living to be 100 .

Richard Smith, MB, BSC, is assistant editor, $B M \mathcal{F}$.

The sketches of Sir Harry were drawn by Ghislaine Howard, an artist living and working in Glossop, Derbyshire. She was trained at Newcastle University and has exhibited in Britain and abroad.

\section{Reference}

1 Platt H. A ramble in nostalgia. Modern Medicine 1971 May 31:161-72.

\section{CLINICAL CURIO}

\section{Spurious ventricular tachycardia with temporary transvenous pacemakers}

We describe two cases in which manipulation of an external pulse generator by the patients led to the erroneous diagnosis of ventricular tachycardia.

Case 1-A 76 year old man had a temporary pacing system inserted for symptomatic complete heart block. Eight hours later he developed a ventricular tachycardia (figure). A direct current counter shock was applied with no success. Before a second shock was given the pacemaker was turned off and the tachycardia stopped. When it was turned on the arrhythmia again restarted. It was then noted that the rate key had been turned and the effective pacing rate was 210 beats/min, producing a monitor trace which was extremely difficult to distinguish from a natural ventricular tachycardia. or disorientated. Fortunately, neither patient suffered any long term ill effects and both had permanent pacemakers implanted successfully. - M B BUCHALTER, department of cardiology, Royal City of Dublin Hospital, Dublin 4, and E T williams, department of cardiology, St Vincent's Hospital, Dublin 4

1 Chung EK. Artificial cardiac pacing. New York: Williams and Wilkins, 1984

2 Kallenbach J, Scott Miller RN, Obel JWP. Runaway temporary pacemaker. Heart Lung 1977;6:517.

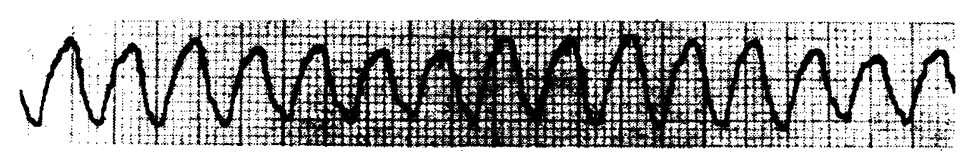

Monitor trace from patient in case 1 during rapid ventricular pacing.

Case 2-An 82 year old man had a temporary pacing system inserted. Several hours later his monitor showed a ventricular tachycardia. Again it was noted that the rate of his pulse generator had been increased to 180 beats/ min, presumably by the patient in his disorientated state, causing the tachycardia.

Arrhythmias may arise in association with temporary pacemakers in several ways. Ventricular fibrillation due to ventricular irritation by the electrode has been described, usually in patients with acute myocardial infarction. ${ }^{1} \mathrm{~A}$ runaway temporary pacemaker leads to rapid pulse generator discharge and subsequent tachycardia and is usually caused by electrical faults within the generator. ${ }^{2}$ This may easily be confused with tachycardias originating in the ventricle itself.

In both our patients the first indication of a problem was the appearance of a rapid wide complex arrhythmia. It was assumed that this originated in the myocardium, and treatment was given accordingly. Fortunately, the true cause was quickly discovered but not until the first patient had undergone a direct current shock. This illustrates the danger of having the controls of external appliances within the reach of patients, particularly if they are old
What is the significance of persistent slight haemoglobinuria in otherwise normal urine in a woman aged 63? A full blood count shows no evidence of haemolysis or other abnormality. She has no symptoms except general fatigue. What further investigations are required?

The first thing to ascertain is are you dealing with haemoglobinuria or haematuria. Both will give a positive result on the test strip. If microscopy of the urine has not been performed this should be rectified. It is, however, important to remember that red cells may lyse in an alkaline urine and intact red cells may then not be seen by microscopy. If investigations show you are dealing with haematuria this will require a full urological/nephrological workup to exclude disease, although it is possible for there to be mild persistent haematuria in patients with no obvious disease. If the patient has haemoglobinuria one would also expect haemosiderinuria. This is easy to test for by arranging for a Perl's stain of the sediment from an early morning urine. Mild haemolysis may be present even when the blood count and reticulocyte count are normal. One would also expect the serum haptoglobins to be reduced or absent when there is sufficient intravascular haemolysis to lead to haemoglobinuria. The logical investigation of intravascular haemolysis will depend on a full history and examination, in particular taking note of any drug history. Finally, it should be remembered that myoglobin will catalyse the oxidation of the indicator contained in the test paper and there are several rare causes of persistent myoglobinuria. The cause of the positive test is unlikely to be myoglobin if the serum creatinine phosphokinase activity is normal.-D R HUTTON, senior lecturer in haematology, Cardiff. 